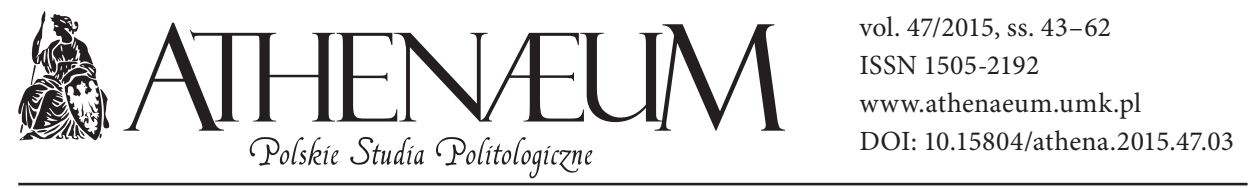

\title{
METATEORETYCZNA ANALIZA ARKUSZA RECENZYJNEGO CZASOPISMA INDEKSOWANEGO „ATHENAEUM. POLSKIE STUDIA POLITOLOGICZNE"*
}

\author{
Łukasz Młyńczyk**
}

\author{
METATHEORETICAL ANALYSIS SHEET REVIEW OF JURNAL \\ INDEXED "ATHENAEUM. POLISH POLITICAL SCIENCE STUDIES"
}

\section{- ABSTRACT}

The objective of article is metatheoretical analysis sheet review, first of all with epistemological and ontological condition, and subsequently methodological issues, that the Reviewer must take into account when assessing and are suitable academic qualifications to the journal indexed. The Review is not only the limitation to the knowledge, but also research and professional qualification.

\section{KEYWORDS}

metatheory, metatheoretical evaluation, political science, journals of political science, parameterization

* Opis czasopisma: „Periodyk „Athenaeum. Polskie Studia Politologiczne” [dalej w tekście: „Athenaeum"] w swym zamyśle jest pismem konsolidującym polskie środowisko politologiczne. U podstaw tej inicjatywy legła głęboka nadzieja na powołanie do życia czasopisma kompletnego, zarówno pod względem merytorycznym, jak i spełniającego funkcję katalizującą badania na gruncie szeroko pojętej politologii. Jego priorytetowym celem jest więc zapewnienie wysokiej komunikowalności w ramach polskiego środowiska politologicznego i stworzenie szansy pełniejszego udziału polskiej politologii na forum międzynarodowej wymiany myśli. Wśród inicjatorów i członków Redakcji istnieje świadomość wyjątkowości polskiej historii ostatnich sześćdziesięciu lat, co może i powinno stać się cennym doświadczeniem dla politologii poza granicami naszego kraju. Począwszy od 2013 r., każdy czwarty numer pisma w roku będzie się ukazywał w języku angielskim jako „Athenaeum. Polish Political Science Studies”. Zob. „Athenaeum. Polskie Studia Politologiczne” (p-ISSN: 1505-2192), http://journals.indexcopernicus.com/Athenaeum+Polskie+Studia+Politologiczne,p4071,6.html, odczyt z dn. 10.01.2015.

** Uniwersytet Zielonogórski, Instytut Politologii. 


\section{WSTĘP}

Jedną z fundamentalnych zasad ewaluacyjnych czasopism naukowych jest stworzenie oraz wypełnianie arkusza recenzyjnego. Wedle zobiektywizowanych reguł parametryzacji powołany do oceny tekstu przesłanego do redakcji. Recenzent, $\mathrm{z}$ reguły będący samodzielnym pracownikiem nauki, ma reprezentować stan znajomości opisywanej w artykule tematyki na poziomie pozwalającym na wydanie „merytorycznego wyroku”. Ów skutkuje uznaniem za warte umieszczenia przedmiotu oceny w naukowym obiegu, którego zasoby poddawane są permanentnej intersubiektywnej weryfikacji. Obok tego nadaje się temu zjawisku rangę obiektywizującą sprawiedliwy podział środków na naukę w Polsce. Ministerstwo Nauki i Szkolnictwa Wyższego (dalej MNiSW) w zakresie swoich kompetencji prowadzi okresowy sprawdzian indeksowanych czasopism pod względem spełniania kryteriów naukowych, ocenianych skwantyfikowanymi parametrami. W konsekwencji sprowadza się to do konwencjonalnego werdyktu o naukowości prezentowanych w danym periodyku treści. Uogólniony zestaw ocen nie gwarantuje oczywiście wyizolowania kwalifikowanych cech dyscypliny w parametrach każdego pojedynczego tytułu, ponieważ trudno zakładać powołanie w obrębie Ministerstwa zespołu stanowiącego reprezentację wszystkich dyscyplin naukowych, nie mówiąc już o pojawiających się węższych specjalizacjach w postaci reprezentantów subdyscyplin, podejść czy ujęć metodologicznych ${ }^{1}$. W tym sensie sam arkusz recenzji jest dla MNiSW rodzajem zaświadczenia o naukowości podmiotu oraz przedmiotu badania (jako wszechstronnej, wyrażonej resortowo miary), abstrahując od słabości kognitywnej poszczególnych nauk. W takim momencie zazwyczaj pojawiają się argumenty o uniwersalnych probierzach przy akompaniamencie, usprawiedliwiających taki wybór, głosów o samoświadomości środowiska wobec faktu wszelkich niedoskonałości tych rozwiązań.

1 Zob. Zarządzenie Ministra Nauki i Szkolnictwa Wyższego z dnia 29 marca 2012 roku w sprawie powołania Zespołu specjalistycznego do oceny czasopism naukowych dla potrzeb przyszłej oceny parametrycznej i sporządzenia wykazu wybranych czasopism naukowych, http://www.nauka.gov.pl/g2/ oryginal/2013_05/bfc36c55d5e715bee562b6159d151322.pdf, odczyt z dn. 09.01.2015. 


\section{STANOWISKO KOGNITYWNE}

W niniejszym artykule nie będą wprost analizowane instytucjonalne parametry oraz kryteria oceny, lecz zostanie podjęta próba umieszczenia ich wykładni w kontekście metateoretycznej analizy arkusza recenzji kwartalnika „Athenaeum. Polskie Studia Politologiczne2" (indeksowane: IC Journals Master List ${ }^{3}$ ) z punktu widzenia wskaźników poznania naukowego, ze szczególnym uwzględnieniem konsekwencji kognitywnych dla samej politologii. Opis podłoża metodologicznego samego druku recenzyjnego to element o niewielkiej wartości eksplanacyjnej. Daleko ważniejsza wydaje się jego dekonstrukcja metateoretyczna, która w założeniu pozwala (lub nie pozwala) na rozpoznanie dorobku politologów z punktu widzenia obiektywnych ograniczeń ich dyscypliny badań. W dalszej kolejności informuje nas o samej efektywności badań teoretycznych. Analiza samej karty oceny musi być prowadzona w kontekście przedmiotu poznania oraz badania, a to jednocześnie wiąże się z oznaczeniem tego, co nie tworzy samo przez się typowych arytmetycznych wskaźników naukowej ewaluacji. Proponuję zatem jako podstawowe kwestie przyjąć weryfikację arkusza pod względem metateoretycznym, w tym odniesienia do założeń filozofii nauki oraz warunków epistemologicznych i ontologicznych (ontycznych). Pozwoli to prawdopodobnie określić stopień asercji wiedzy o naukowości dowolnie ocenianego artykułu poprzez następujące odniesienia do poziomu teoretycznego dorobku politologii jako dyscypliny nauk społecznych.

Z powyższych założeń wynikają problem badawczy oraz stosowne hipotezy, tyle że wyrażone implicite. Jest to świadomy zabieg, ponieważ celem artykułu ma być wykazanie zbyt dowolnego traktowania kategorii metodologicznych przez przedstawicieli nauk politycznych, co skutkuje rozmijaniem się oczekiwań oraz efektów wysiłków autorów oraz recenzentów prac naukowych. Założenia metodologiczne przyjęte przez polskie środowisko politologiczne są w pewien sposób traktowane intuicyjnie, nie zaś intencjonalnie, zgodnie z ich faktycznym

${ }^{2}$ Czasopismo według współczynnika MNiSW obowiązującego w roku 2014 dysponuje liczbą 8 punktów za publikację artykułu naukowego na jego łamach. Zob. Komunikat Ministra Nauki i Szkolnictwa Wyższego w sprawie czasopism naukowych, http://www.nauka.gov.pl/komunikaty/komunikat-ministra-nauki-i-szkolnictwa-wyzszego-w-sprawie-wykazu-czasopism-naukowych.html, odczyt $\mathrm{z}$ dn. 10.01.2015.

3 Zob. „Athenaeum. Polskie Studia Politologiczne” (p-ISSN: 1505-2192), http://journals.indexcopernicus.com/Athenaeum+Polskie+Studia+Politologiczne,p4071,6.html, odczyt z dn.10.01.2015. 
przeznaczeniem. Intuicja naukowa to pełnoprawny składnik badania naukowego, jednak dopuszczony do użytku jako element pewnej bezalternatywnej sekwencji działań. Ma raczej szkodliwe konsekwencje, kiedy jest wynikiem stanu niewiedzy oraz wyłącznym przymusem arkusza recenzyjnego. W sytuacji, kiedy pozostaje w izolacji, wypełnia treścią rodzaj przykrego obowiązku, którego nieumieszczenie po zakończeniu wywodu w jego wstępie skutkuje obniżeniem, względnie odrzuceniem całości tekstu z przyczyn formalnych lub z powodu przekonania o istnieniu stałej linii demarkacyjnej między tym, co naukowe i nienaukowe. Podstawowym zaniedbaniem politologów jest błędne zestawianie ze sobą nauki w rozumieniu Arystotelesowskim z konsekwencjami istnienia politologii jako nauki o rozmytym przedmiocie badania. Kategorię tę w odniesieniu do polityki zaproponował Filip Pierzchalski . Znakomicie oddaje ona słabości empirycznego dowodu naukowego przyjmowanego i kolportowanego przez politologów. Zauważmy, że krytyczna analiza praktyk polskich politologów traktowana byłaby zbyt personalnie, dlatego też świadomie używa się błędu przesunięcia kategorialnego, informując o grzechach i błędnym myśleniu politologii, nie zaś jej podmiotów sprawczych. Analogia ta koresponduje z zachowaniami samych polityków, którzy w wyborach mówią o własnych zaletach, nigdy zaś nie eksponując zdobyczy samej polityki. Ta traktowana jest intencjonalnie jako emitent złych praktyk.

W owym zbiorze rozmytym, wskazuje F. Pierzchalski, mieszczą się elementy intencjonalnie do niego zakwalifikowane ${ }^{5}$. Nie wynika to oczywiście z dowolności tych osobistych redukcji. Mamy wobec tego zbiór kwalifikowanych cech, co do których zasadne jest twierdzić, że ich stałą własnością jest pozostawanie w orbicie tego, co polityczne. W ten sposób można odnieść się do postulatu zgłoszonego przez Adama Groblera, aby nasz wybór konwencji metodologicznej, rozumianej jako zasada wnioskowania do najlepszego wyjaśnienia, traktowany był analogicznie jak w przypadku nauk przyrodniczych ${ }^{6}$. Politologia to, jak pisze F. Pierzchalski, zbiór analiz kontekstowych, międzyobszarowych, wielopoziomowych, syndromatycznych ${ }^{7}$. Są to ustalenia, jakie w sensie metateoretycznym mogą podnieść wartość samej teorii. Trzeba się zgodzić z autorem, że ścisłe linie demarkacyjne nauk nie przesądzają o jakości samego poznania. W moim prze-

${ }^{4}$ F. Pierzchalski, Polityka jako rozmyty przedmiot badań, [w:] Metafory polityki, t. 4, red. B. Kaczmarek, Warszawa 2013, s. 35-51.

5 Ibidem, s. 36.

${ }^{6}$ A. Grobler, Metodologia nauk, Kraków 2006, s. 237.

7 F. Pierzchalski, op.cit., s. 36. 
konaniu termin interdyscyplinarność utracił jednak swoją moc eksplikatywną. Politologia w pewnym sensie, poprzez funkcjonowanie w obszarze nauk społecznych, ma okresową relewantną przewagę nad siostrzanymi dyscyplinami. Nie jest to jednak i zapewne nigdy nie będzie wyższość metateoretyczna, a wyłącznie oparcie się na przedmiocie poznania, który w określonych kontekstach społecznych zyskuje dominujący status. Rozwijając tę myśl, można stwierdzić, że postulowana $\mathrm{w}$ rozmaitych recenzjach kategoria odniesienia się do znaczącego wkładu w rozwój dyscypliny w przypadku politologii jest również możliwością kontynuowania procesów poznawczych w miejscach, w jakich zakończyli swoją aktywność badacze innych dziedzin społecznych. W sensie teoretycznym przypomina więc politologia konstytuowanie się pojęcia polityczności Carla Schmitta, bowiem poprzez sprawcze implikacje swojego przedmiotu poznania powoduje, że kategorie psychologiczne ekonomiczne, prawne, socjologiczne, antropologiczne, etc. zyskują politologiczny status, o ile wiodą do chęci odkrycia kolejnego etapu ewolucji istoty badań społecznych. Chodzi zatem nie o ściśle rozumianą interdyscyplinarność ani wzajemne wnikanie w pole swoich badań, lecz przejście do kontekstów, które formalnie nie dominują już w pokrewnych dyscyplinach. Najogólniej rzecz ujmując, można by twierdzić, że w treści opisu teoretycznego rozwój człowieka, istoty społecznej, utrwala się i najpełniej realizuje w tym, co polityczne. Nie oznacza to jednak postulatu wyższości nauk politycznych nad pozostałymi pokrewnymi sobie. W sensie deskrypcyjnym sytuacja ta przypomina funkcje samolotu, gdzie jego rozbiegiem, wznoszeniem oraz lotem interesują się inne subdyscypliny i opisują to odmienne prawa. Samolot osiąga bowiem swoje apogeum w postaci lotu (ten jest jego potencjalnością), zaś człowiek w formie społecznie widzianego rozwoju politycznego. W sensie czysto poznawczym każdy etap jest jednakowo ważny ${ }^{8}$. Można odnieść mylne wrażenie, że pomiędzy naukami wywodzącymi się z tej samej rodziny nie zachodzi wewnętrzna rywalizacja. Kiedy jednak uświadomimy sobie, że każda ewaluacja ma w konsekwencji wskazać na konwencjonalną wartość, wówczas współzawodnictwo, nawet implicite wyrażone, zaczyna organizować schemat naszych naukowych praktyk. Mamy więc obok zobiektywizowanego oszacowania niematerialnego (uznanie) także materialny, a dziś również komercyjny wynik, który wymyka się uogólnionym kryteriom. „W nauce, podobnie jak i nieomal we wszystkich dziedzinach życia,

8 Zob. A. Giddens, Poza lewica i prawica, Poznań 2001; I. Krastew, Demokracja nieufnych: eseje polityczne, Warszawa 2013. 
trwa jednak rywalizacja o prestiż, siłę oddziaływania, a także o pieniądze" język jest w stanie dostarczyć nam satysfakcjonujących desygnatów terminu znaczacy wkład, o tyle jego materialne i nominałowe wcielenie pozostaje dla nas wciąż nieprecyzyjnym oszacowaniem. Powyższe okoliczności sprzyjają niestety także naukowym fałszerstwom, ponieważ zarówno akceptacja środowiska, medialny rozgłos, jak i komercyjne zastosowanie stanowią jednostkową naukową użyteczność ${ }^{10}$. Zwykle presja związana $\mathrm{z}$ czasem przeznaczonym na zdobycie stopni oraz tytułu naukowego warunkuje postawy częściowo konformistyczne, nawet jeśli zgodne z prawem, to jednak wprowadzające wątpliwości natury etycznej ${ }^{11}$, a przede wszystkim poznawczej i metodologicznej. Jednak w przypadku tych ostatnich upowszechniło się stanowisko, które określić można zmieszczeniem się w kategorii naukowości, jako że tradycyjna deskrypcja koresponduje $\mathrm{z}$ doniosłością na bardzo podstawowym poziomie.

\section{ZAŁOŻENIA EPISTEMOLOGICZNE ORAZ ONTOLOGICZNE, CZYLI CO UWZGLĘDNIA RECENZENT}

W zasadzie już samo przyjęcie kryterium epistemologicznego i ontologicznego unaocznia nam nieuchronnie każdorazowo teleologiczną funkcję przeprowadzanego badania. Badacze, sytuując się w obszarze tego, co podlega ich eksploracji, działają często intencjonalnie. W przypadku politologów owo usytuowanie jest cechą permanentną, od której w zasadzie nie wolno abstrahować. Idąc w ślad za Janem Woleńskim ${ }^{12}$, co potwierdza również Tadeusz Klementewicz ${ }^{13}$, można wyodrębnić w badawczym zestawie politologa poziomy epistemiczny oraz epistemologiczny. Pierwszy odniesiony do rzeczy będzie mieć cechy przedmiotowe.

9 J. Wilkin, Ocena parametryczna czasopism naukowych $w$ Polsce - podstawy metodologiczne, znaczenie praktyczne, trudności realizacji i perspektywy, https://forumakademickie.pl/aktualnosci/2013/1/14/1315/ocena-parametryczna-czasopism-naukowych-w-polsce-podstawymetodologiczne-znaczenie-praktyczne-trudnosci-realizacji-i-perspektywy/\#, odczyt z dn. 16.01.2015.

10 Zob. T. Stawiszyński, Kanciarz z tytułami, „Newsweek” 2001, nr 46; B. Carey, Fraud Case Seen as a Red Flag for Psychology Research, „New York Times”, 2 November 2011; R. Marszałek, Wzór na naukowy przekręt, „,Gazeta Wyborcza”, 11.12.2014; Y. Bhattatcharjee, The Mind of Con Man, „New York Times”, 26.04.2013. Warto zaznaczyć, że Redakcja „Athenaeum. Polskie Studia Politologiczne” wprowadziła i stosuje zaporę ghostwriting.

11 Por. J. Woleński, Uwagi o ewaluacji czasopism naukowych, „Nauka” 2013, nr 1, s. 57.

12 Por. idem, Epistemologia: poznanie, prawda, wiedza, realizm, Warszawa 2005, s. 58.

13 T. Klementewicz, Rozumienie polityki: zarys metodologii nauki o polityce, Warszawa 2011, s. 30. 
Przedmiotem wiedzy są zatem pojęcie, twierdzenie, definicja, teoria oraz prawo. W rozumieniu ultradyscyplinowym będą to czynności poznawcze, problemy badawcze, aparaty terminologiczne oraz wiedza ogólna o człowieku i społeczeństwie $^{14}$. Poziom epistemologiczny ma cechy metaprzedmiotowe, więc aplikuje do wiedzy o rzeczach: akt poznawczy oraz jego wytwór ${ }^{15}$. Uściślając powyższe założenia dla samej politologii, otrzymamy kognitywny zestaw elementów życia politycznego składający się z dorobku badawczego wszystkich empirycznych nauk społecznych, odnoszących się w przedmiocie badań do cech politycznych życia społecznego ${ }^{16}$. Już na wspomnianym poziomie epistemicznym możemy dostrzec umyślność poznawczą badaczy. Jeśli dopuścimy pogląd naturalistów, że istotą epistemologii jest opis tego, jak ludzie poznają, to jednak nie możemy zapominać, że sam proces naukowy jest funkcją chęci poznania. Ta ostatnia wypływa przede wszystkim z osobistego przekonania o jego możliwościach, co zakłada już z góry nasze pragnienie nakłonienia odbiorców do przyjęcia postulowanego schematu rozumowania, a stąd już tylko krok do przypisywania mu słuszności. Barbara Krauz-Mozer zarówno wyjaśnienie, jak i rozumienie zjawisk uzależnia od wyboru narzędzi odpowiednich do celu i przedmiotu badania ${ }^{17}$. To wszystko odtwarza się w przypadku merytorycznego wglądu w sam proces recenzowania na potrzeby czasopisma politologicznego. Recenzowana jest nie tylko kwalifikacja metodologiczna autora, ale również jego implicite wskazana afiliacja kognitywna. Mamy bowiem ogólne założenia dotyczące metateorii nauki, ale konfrontujemy je ze specyfiką dyscypliny oraz indywidualnym preferowaniem konkretnej orientacji przez recenzenta. Wbrew pozorom ten ostatni problem decyduje $\mathrm{w}$ istotnym stopniu o losie nie podmiotu (autora), lecz przedmiotu oceny (tekstu), w konsekwencji mogącej sytuować ten ostatni w zasobach nauki. Jakikolwiek arkusz oceny, nawet gdyby rozbudować go o zadeklarowanie przez branżowego krytyka stanowiska metateoretycznego, nie przesądza o naukowym (w sensie treściowym, a nie instytucjonalnym) przeznaczeniu samego badania w dającej się wyobrazić przyszłości. Widzimy więc, że powstaje okoliczność, kiedy można/należy zachować daleko idącą powściągliwość.

14 Ibidem.

15 J. Woleński, Epistemologia..., op.cit., s. 58.

16 T. Klementewicz, op.cit., s. 30.

17 B. Krauz-Mozer, Metodologia jako forma samowiedzy badawczej, [w:] Aspekty metodologiczne oraz teoretyczne w subdyscyplinach politologii, red. Ł. Młyńczyk, B. Nitschke, Toruń 2013, s. 53. 


\section{METATEORETYCZNA EWALUACJA PYTAŃ RECENZYJNYCH}

Pierwszym pytaniem kwalifikującym tekst do „Athenaeum” jest: czy artykut prezentuje wyniki oryginalnych badań o charakterze empirycznym, teoretycznym lub analitycznym?, co w przypadku wyraźnego sprzeciwu recenzenta (choć formalnie brak jest takiej możliwości opisowej oraz wariantowej poza dychotomią „tak lub nie”) mogłoby determinować odpowiedzi na kolejne, a w konsekwencji samą ocenę. Umieszczenie tego zagadnienia na czele pytań recenzyjnych pozwala widzieć w nim decyzję o literalnie rozumianej kwalifikacji naukowej. Nie przesądza to jednak o braku alternatywy wobec konieczności zanegowania tekstu w całości. Subiektywna miara oryginalności musi bowiem uwzględniać ocenę założeń poznawczych, na mocy których zero-jedynkowy werdykt zostaje uwikłany w problem metarefleksji, jeśli nie można go sprowadzić do kompilacji powszechnie dostępnych zasobów literatury.

$\mathrm{Z}$ formalnego punktu widzenia bardzo trudno jest odrzucić artykuł, który nie mieści się w przyjmowanym przez podmiot oceniający stanowisku kognitywnym. Odnieśmy tę kwestię do pytania $\mathrm{z}$ arkusza recenzji: czy zagadnienie przedstawione $w$ artykule posiada walory aplikacyjne (czy może zainteresować również nie-politologów)?. Założenie, jakie wynika z powyższego, można zrozumieć jako wskaźnik aplikacji nie tylko w rozumieniu transdyscyplinowym, ale również praktycznym, a nawet komercyjnym. W logicznie ujętym zbiorze „nie-politologów” mieszczą się bowiem wszyscy, dla których nieprawdziwe jest zdanie: „jestem politologiem"18. Mogą to być reprezentanci innych nauk, ale również biorcy atrakcyjnych komercyjnie treści politologicznych, np. dziennikarze, politycy, filmowcy etc. Kwestia, czy wytworzenie się tego typu relacji mieści się w zobiektywizowanych kryteriach oceny potencjału naukowego, pozostaje nierozwiązywalna w oparciu o wskaźniki pozanaukowe, lecz przecież dopuszczone przez sam Arkusz. Pozostając w optyce stricte naukowej, zakładamy, że artykuły $\mathrm{w}$ czasopiśmie indeksowanym z założenia powinny podlegać rozpowszechnianiu na mocy bycia reprezentatywnymi dla owego parametru. Kolejnym współczynnikiem będzie wykazana indeksem Hirscha liczba cytowań w formie dystrybutywnej. Wysokość limitu punktów wskazuje z jednej strony na uogólnioną

18 Przenosząc to na poziom empiryczny, dokonać musimy rozgraniczenia na politologów uprawiających zawód oraz absolwentów studiów politologicznych. Jeśli ci drudzy nie prowadzą systematycznych i osadzonych w teorii dyscypliny badań naukowych, w praktyce zaliczają się do zbioru „nie-politologów”. 
wartość samego czasopisma. Jest przy tym również formatem samospełniającej się przepowiedni, ponieważ uruchamia sekwencję wniosków: znacząca liczba punktów - znaczące czasopismo - znacząca publikacja - obiektywna potrzeba zacytowania - indeks Hirscha - intersubiektywna wartość naukowa. Tego typu konsekwencje, przy uwzględnieniu ich przez środowiska niechętne kwantyfikacji walorów naukowych, wpływają na ocenę samego procesu licencjonowania treści periodyków naukowych. Problem, będący lejtmotywem sporu pomiędzy zwolennikami a oponentami kryteriów liczbowych, choć jest roztrząsany przez naukowców, to jednak w dużej części dotyczy sądów wartościujących, a więc ma postać debaty nienaukowej. Własne odczucia wobec przyjętego wzorca nakreślają istotę problemu, lecz nie rozwiązują go ani na poziomie teoretycznym, ani metateoretycznym ${ }^{19}$. Podobnie należałoby uczynić $\mathrm{z}$ ograniczającymi swobodny dyskurs, niewyartykułowanymi explicite uprzedzeniami. Nie ma przy tym znaczenia, że sprowadzając całe to zjawisko do upowszechnionych, choć nie naukowych reguł zdrowego rozsądku, większość z nas przysposobi sobie argumenty jakościowe ponad ilościowe. Kwantyfikacja ocen, takich jak koncepcja Hirscha, w odniesieniu jej do konkretnego środowiska naukowego (państwa), pozwala zobiektywizować kryteria jakościowe ${ }^{20}$. Ponownie trzeba jednak zastosować właściwe uogólnienie. W wypadku nauk ścisłych (przyrodniczych) problem badawczy zasadniczo ma charakter abstrakcyjny oraz stosunkowo rzadko odnoszący się do czasu oraz przestrzeni. Możliwości aplikacyjne tego rodzaju badań są praktycznie nieograniczone. Trudno zakładać, że fizyk czy chemik separują pole swoich dociekań do własnego mikroświata w wymiarze temporalnym ${ }^{21}$. Tymczasem w przypadku nauk o przedmiocie poznania immanentnie związanym z przestrzenią społeczno-polityczną tego typu redukcje są często sensem prowadzonych badań. Promowanie mniejszej liczby dobrych publikacji ma niewiele wspólnego z nadawaniem takiemu określeniu funkcji miernika jakościowego, lecz właśnie sumarycznego ${ }^{22}$. W ten sposób określenie znaczacy dorobek jest

19 Por. A. Rychard, Humanistyczna szczepionka dla wszystkich, „Gazeta Wyborcza”, 6.03.2014; I. Krzemiński, Jak popsuli naukę, „Magazyn Świąteczny-Gazeta Wyborcza”, 17-18.05.2014; Ł. Budzicz, Wole punkty od kolesiów, „Magazyn Świąteczny - Gazeta Wyborcza”, 24-25.05.2014.

20 Por. K. Sangwal, On the relationship between citations of publication output and Hirsch index $h$ of authors: conceptualization of tapered Hirsch index $h T$, circular citation area radius $R$ and citation acceleration $a$, „Scientometrics” 2012, No. 93, s. 987-1004, http://download.springer.com/static/ pdf/675/art\%253A10.1007\%252Fs11192-012-0805-7.pdf?auth66=1421080718_ffaf33759b337ac7e18480832a5caaaa\&ext=.pdf, odczyt $\mathrm{z}$ dn. 12.01.2015.

${ }^{21}$ Por. ibidem, s. 988-989.

22 Por. J. Wilkin, op.cit. (vide: założenia dotyczące bibliometrii). 
funkcją spełnienia kryterium, a nie jego opisania. Tego rodzaju kwalifikacja zapewne nie przekonuje oponentów. Określając walory, recenzent wskazuje na możliwość aplikacji naukowej w środowisku politologów, w szerszym ujęciu także poza granicami państwa. Innym typem wdrożenia jest obiektywna miara wartości naukowej, odnosząca się do nowatorskiego opracowania zagadnienia i jego implementacji, jednak w sensie nie ściśle patentowym, lecz użytkowym. W związku z powyższym nie sposób rozstrzygnąć, czy nadawana liczba punktów $\mathrm{w}$ identycznym stopniu odzwierciedla owe pozytywy w przypadku artykułu publikowanego w języku polskim oraz w języku angielskim. Mankamentem translacji języka jest jego niedosłowna przekładalność, jednak w przypadku tłumaczenia schematu rozumienia pojawia się obiektywna konieczność opisu warunków wstępnych. Widać więc, że indeks nie zabezpiecza przed sytuacją, w jakiej subiektywne przekonanie o przewadze wartości jednej własnej publikacji nad inną nie koresponduje $\mathrm{z}$ wynikiem samego pomiaru, gdzie sytuacja może być zgoła odwrotna, przy czym taka „popularność” nie przesądza o niezawodnej gradacji. W tej sytuacji znaczenia nabiera ocena języka narracji naukowej, który prezentuje badacz. Pytania arkusza: czy język artykułu jest poprawny?; czy zagadnienia artykułu zostały przedstawione w sposób zrozumiały? odnoszą się do powyższego zagadnienia. Język, jakim posługują się politolodzy, ma funkcjonalny charakter, natomiast terminologia dyscypliny to pole nieustannych negocjacji metateoretycznych. Klasyczne pojęcie polityki oraz stopniowo emancypujące się pojęcie polityczności nie doczekały się satysfakcjonującego rozpoznania definicyjnego. Od razu zakładam, że owo spełnienie dotyczy w zasadzie wyłącznie kognitywnych purystów. Na poziomie analiz posługujemy się bowiem pojęciami o materialnym oraz niematerialnym statusie, których częściowo dotyczy podwójna abstrakcyjność. Zatem desygnatami pojęcia Ewa Kopacz są człowiek (pierwsza reprezentacja) oraz premier (funkcja/instytucja), pozostający pierwotnie człowiekiem (druga reprezentacja). Kolejną fazą byłoby dodanie tym tożsamościom desygnatu płci. Po nominacji Ewy Kopacz na stanowisko prezesa Rady Ministrów pojawiły się przekazy akcentujące płeć nowej pani premier. Sformułowania: „premier jest kobietą” oraz „kobieta jest premierem” nie pozostają $\mathrm{w}$ równowadze teoretycznej dla przedstawicieli nauk społecznych i są odczytywane dziś w dominującym kodzie przede wszystkim kulturowym (już pozajęzykoznawczo). Na poziomie metateorii należałoby taką teorię wyjaśnić także poprzez niematerialność przedmiotu poznania politologii. W takim przypadku poprawność języka ma wariant intersubiektywnie semiotyczny, ale również intencyjnie kontekstowy, dyscyplinowy oraz epistemologiczny. 
Sprawa komplikuje się znaczniej w przypadku żądania zrozumiałej artykulacji wykładu. Jeśli nawet uda nam się przekroczyć konwencję samego języka, to faktycznie docieramy do punktu, w którym posługujemy się wykładnią pojęć, które nie mogą zostać uściślone bądź mają charakter raczej płytkich metafor. Rozpoznanie ich sensu przechodzi z poziomu semiotyki na poziom orientacji ontologiczno-epistemologicznej, odnoszącej się bezpośrednio do podmiotu poznającego oraz sposobu poznania. Wówczas pojęcie abstrahujące od desygnatu (polityczność) może stać się nie tylko składnikiem teorii, ale również tłumaczyć zmianę wartości kategorii będących jej częścią. Wtedy uwidacznia się relewantność przedmiotu dociekań politologii, ponieważ komponenty teorii zyskują nowy walor eksplikatywny. Zatem postulowanie interdyscyplinarności badań przestaje być miernikiem i musi być widziane jako skutek pozostawania w obszarze nauk społecznych. Tak rozumiana nasza dyscyplina nie jest czymś wyjątkowym, lecz redukuje się do elementu katalogu podejść.

Wyjaśnienie oraz rozumienie to schematy pochodzące $\mathrm{z}$ dwóch poznawczych światów. Pierwszy odnosi się do nauk przyrodniczych (zestawu praw), podczas gdy drugi pozwala rozpoznać kulturę, to jest zestaw zjawisk jako wytworów ludzkiego ducha ${ }^{23}$. W takim aliansie rozumiejacego naturalizmu sama polityczność zyskuje stosowną wartość aplikacyjną dla politologów ${ }^{24}$. Nie oznacza to jednak wskazania gotowej ścieżki recenzyjnej, lecz głównie niezbędności dokonania określonej reorientacji oraz dekonstrukcji myślenia samego autora artykułu, nawet kiedy deklaratywnie lub pośrednio przyjął odmienny punkt widzenia ${ }^{25}$.

Zrozumiałe przedstawienie zagadnień jest łączone $\mathrm{z}$ wyższością preferowanego stanowiska przez samego recenzenta. Możemy mu przypisać rolę wychowawcy, bowiem „nagradza bądź karze” oznajmujące wypowiedzi jednostki, jednak sam uprzednio dziedziczy uwikłanie w pozawerbalne oraz werbalne skojarzenia empiryczne ${ }^{26}$. Wdrażanie i egzekwowanie form języka naukowego jest więc częścią wcielenia podmiotu recenzji do kultury naukowej społeczności badaczy. W przypadku, kiedy społeczność naukowców akceptuje jedne wzory oceniania dowodów naukowych kosztem innych, angażuje się na mocy osobistej deklaracji oraz nieformalnego aktu inkluzji w ów nieunikniony spór ${ }^{27}$.

23 A. Grobler, op.cit., s. 223.

24 Por. ibidem, s. 230-237; J. Topolski, Rozumienie historii, Warszawa 1978, s. 190.

25 Por. P. Godfrey-Smith, Theory and Reality: An Introduction to the Philosophy of Science, Chicago-London 2003, s. 150-155.

${ }^{26}$ J. Kmita, Wymykanie się uniwersaliom, Warszawa 2000, s. 33-34.

27 Por. S. Amsterdamski, Tertium non datur? Szkice i polemiki, Warszawa 1994, s. 77. 
Podobnie dzieje się w przypadku ewaluacji sygnałów włączenia własnych badań w obszar paradygmatu. Jest to swoiste unaukowienie, ponieważ istotowo może być zidentyfikowane jako obietnica bez pokrycia. Tym niemniej w wymiarze funkcjonalnym odnieść to musimy do kwestii zrozumienia. To ostatnie, choć odnosi się bezpośrednio do samego rozumienia, nie oznacza jednak wskazywania bezalternatywnej procedury poznawczej dla politologii. Chodzi zatem o jasność (klarowność) wykładu, a nie naukową empatię (Verstehen). Możemy jednak wyobrazić sobie sytuację, kiedy recenzent zweryfikuje artykuł pod kątem strategii rozumienia (wnioskowania), co nie może być w żadnym przypadku niewłaściwym wyborem. To wszystko ma niewiele wspólnego z wykładnią samych pojęć, a do tradycyjnej poprawności języka nie odnosi się już zupełnie. Trudno oczekiwać, że poddamy weryfikacji artykuł autora, który nie radzi sobie z formułowaniem zdań w przyjętym konwencjonalnym języku wypowiedzi. Co więcej, pytanie to nie warunkuje, czy mamy do czynienia z błędami merytorycznymi czy z hermetycznym pojęciowo stylem narracji.

Kwestia odpowiedniej długości tekstu wyrażona w wymogach redakcyjnych, a korespondująca z pytaniami Arkusza w przypadku „Athenaeum” opiera się na dwóch założeniach. Po pierwsze konwencja samego wyjaśniania naukowego (politologicznego) zakłada pewien standard obszerności artykułu (min. pół arkusza wydawniczego). Po drugie narracja naukowa wymaga określonej konstrukcji, co bezpośrednio implikuje samą wielkość. Ograniczenia redakcyjne z kolei zakładają nieprzekraczanie założonej odgórnie liczby znaków ${ }^{28}$. Widać, że wymagania, jakie stawiane są bezpośrednio autorowi, a pośrednio recenzentowi, nie muszą korespondować na poziomie naukowym $\mathrm{z}$ obiektywnym interesem Redakcji, czego nie możemy sprowadzać do kwestii komercyjnych, lecz konieczności utrzymania resortowych standardów parametryzacyjnych. W omawianym zbiorze umieścić możemy również trzy kolejne pytania: czy autor podejmuje krytyczna dyskusję z literatura przedmiotu?; czy artykut jest opracowaniem oryginalnym, wnoszacym nowe treści do dyskusji naukowej? czy podana literatura w jezyku polskim, angielskim i przedmiotu badania jest reprezentatywna? Zwykle owa nowość, rejestrowana na gruncie treści i metodologii, wskazywana jest wówczas, kiedy przekracza zakresy umieszczone w podręcznikach dyscypliny. Część badaczy w Polsce uznaje za konieczne sprawozdanie ze stanu badań dotyczących prezentowanego przez nich problemu, co w przypadku popularnych politycznych zjawisk musi budzić dwojakie wątpliwości: pierwsza - prezentacja treści

2830000 znaków, http://www.athenaeum.umk.pl/podstrony/autorzy.html. 
upowszechnionych jako świadectwo naukowej erudycji ${ }^{29}$; druga - radykalna przewaga deskrypcji kosztem eksplikacji oraz predykcji. Inny problem stanowi przekonanie o wyższości cytowanych artykułów anglojęzycznych kosztem cytowania polskojęzycznych tekstów, które często nie są nawet wzajemnie czytane ${ }^{30}$. Trzeba zaznaczyć, że uzupełnienie literatury przedmiotu możliwe jest w zasadzie tylko wtedy, kiedy przyswoiło się ją w stopniu ponadprzeciętnym. Ocenia się więc wkład, a nie świadomość publikacyjną autora. Wobec tych założeń standardowa długość tekstu nie podlega krytyce wyłącznie ze względu na subiektywne miary proporcji.

Nieco innej weryfikacji oczekuje się od recenzenta wobec konieczności wydania subiektywnego werdyktu dotyczącego powołania się na reprezentatywność literatury przedmiotu. Rozpoznanie uwzględnia zwykle zakresy ilościowy oraz jakościowy. Określenie reprezentatywna możemy zastąpić terminem „wystarczająca”, będącym pozorną miarą liczbową, ponieważ odnosi się nie do ilości, lecz do funkcji, to jest zaspokojenia potrzeby. Zatem recenzent nie tylko jest podmiotem oceniającym, ale również podlega procedurze testu intersubiektywności. W logice metateorii kategoriom reprezentatywności oraz krytycznej dyskusji autora z literatura przedmiotu (niezależnie od błędu przesunięcia kategorialnego) przypiszemy rolę tym razem postulatu prezentacji najczęściej nie własnych teorii, którym dopisuje się stosowne uzupełnienia lub wykorzystuje się jako podstawę badań autorskich, względnie polemizuje się, negując jej założenia. Oczywiście krytyki naukowej nie utożsamiamy z potoczną negacją, jednak można założyć, że najbardziej pożądaną aktywnością naukową określa się prezentację nowej autorskiej teorii (lub jej założeń wstępnych) jako dowodu sporu $\mathrm{z}$ umieszczonymi w zasobach dyscypliny uprzednimi stanowiskami. Weryfikacji podlega w związku z tym samo subiektywne przekonanie, odpowiednio autora i recenzenta, że istnieje teoretyczny (treściowy) związek między reprezentatywnością literatury a skuteczną z nią dyskusją. To z kolei prowadzi nas do pytania: czy artykuł wprowadza nowe rozwiazania teoretyczne? Zawiera ono w sobie podstawowy i jednocześnie najbardziej ogólny postulat metateoretyczny. Ponownie nie jest on wprost wyartykułowany. Nawet jeśli status orzekania o opracowaniu nowatorskich rozwiązań teoretycznych oprzemy na gruntownej znajomości stanu badań przez recenzenta, nie wypełnia to istoty

\footnotetext{
29 Nieco żartobliwie tę postawę określić można mianem: „książki za nim stoją”.

30 T. Żuradzki, Nowa propozycja kategoryzowania międzynarodowych czasopism filozoficznych, „Nauka” 2014, nr 4, s. 117.
} 
żądanego potwierdzenia. Zakładamy bowiem, że reprezentacją będą tylko te badania, które w nietradycyjny sposób obrazują problem najczęściej istniejący od zawsze. W samym druku recenzyjnym nie założono stopniowania, co redukuje osąd do autorytatywnego stwierdzenia reprezentowanego przez dychotomię: „tak lub nie”. Sam brak „tak” w ocenie nie przesądza o nieuzyskaniu zgody na publikację artykułu. Widać więc, że o ile liczbowa wartość przesądza o całości tekstu, o tyle nie różnicuje wartości własnych składowych.

Załóżmy pewną idealizacyjną wykładnię. Politolog konstruuje artykuł naukowy będący sprawozdaniem z jego wcześniejszych badań, których wynik $\mathrm{w}$ formie opisu teoretycznego pragnie zaprezentować na łamach czasopisma, pełniącego funkcję intersubiektywnego narzędzia zweryfikowania proponowanej materii badawczej. Odrzucamy w ten sposób zarzut o afektywnie motywowaną chęć publikacji w czasopiśmie punktowanym. Zatem podstawowym kryterium, mieszczącym się wśród zasadniczych celów wydawniczych „Athenaeum”, staje się potrzeba naukowego komunikowania i popularyzowania osiągnięć poza granicami kraju (coroczny numer anglojęzyczny). Wobec tego odpowiednio skomponowany kwestionariusz recenzyjny należy traktować funkcjonalnie i służebnie wobec kryterium intersubiektywności jako efektu komunikowania, nie zaś orzeczenia naukowości per se. Ten ostatni warunek uznaje się za domyślnie wynikający ze skutku samej recenzji.

$\mathrm{W}$ druku ewaluacyjnym „Athenaeum” recenzent musi zmierzyć się z odpowiedzią na pytanie: czy zagadnienie przedstawione $w$ artykule jest istotne pod względem naukowym? Należy to uznać za formant wskaźnika głównego kryterium oceny wartości naukowej dorobku habilitanta w postaci posiadania znacznego dorobku $u^{31}$. Można więc dokonać pewnej redukcji, gdzie skwantyfikowana ocena artykułu, poruszającego istotne kwestie naukowe, spełnia i jest tożsama z określeniem znaczności w przypadku ubiegania się o najwyższy stopień naukowy. Obserwujemy w ten sposób pewne sprzężenie oraz wzajemne intersubiektywne sprawdzenie siebie, już w naukowo węższym środowisku recenzentów. Nadanie określonej, skądinąd sporej jak na polskie warunki liczby punktów winno skutkować wzięciem odpowiedzialności za oceniany artykuł, a wartość samej kwalifikacji podnosi procedura double blind review. W konsekwencji powinno to gwarantować, że habilitant uniknie sytuacji, kiedy kolejny recenzent (w przewodzie habilitacyjnym) zakwestionuje naukowy status tej części dorobku. Mamy

31 Ustawa z dnia 14 marca 2003 roku o stopniach naukowych i tytule naukowym oraz stopniach i tytule $w$ dziedzinie sztuki, „Dziennik Ustaw” 2003, nr 65, poz. 595, art. 16. 
bowiem konkretny wskaźnik liczbowy, wypełniający w wysokim stopniu treść desygnatu pojęcia znaczny. Celowo unikamy analizy semiotycznej, ponieważ ta pozostawia pole do dwukierunkowej interpretacji. Miara liczbowa, przy całej jej ułomności, spełnia kryterium niesprzecznego rozumowania, w analizowanym wypadku, o reprezentowanej wartości. Tymczasem opisowa forma recenzji sprowadzana była przez lata do jej funkcji pedagogicznej, gdzie habilitant otrzymywał epicki rejestr własnej niedoskonałości, a często finalnie uzyskiwał zgodę na kontynuowanie ubiegania się o cenzus naukowy. Wobec tego punktacja wyraża normę, która w kontekstualnych warunkach zrównuje ocenę z konkluzją. Pojawia się w tym miejscu dylemat, czy liczby w nauce decydują o samym osiągnięciu czy raczej o zakwalifikowaniu do oceny osiągnięcia. Praktyka naukowo-ewaluacyjna wskazuje, że dominującą miarą jest jednak formuła opisowa, a więc pojęciowo zobiektywizowana subiektywna ocena, reprezentującego kognitywne pokrewieństwo, samodzielnego pracownika nauki. Widzimy zatem, że kluczowa kategoria arkusza zyskuje kwalifikacje intersubiektywne, których rolą jest nie tylko ocena realnego wkładu do dorobku dziedziny, ale również regres do zinstytucjonalizowanej diagnozy kwalifikacji zawodowych.

\section{INŻYNIERIA METODOLOGICZNA POLITOLOGÓW}

Ostatnia część poświęcona zostanie pytaniom, które bezpośrednio odnoszą się do założeń metodologicznych ${ }^{32}$. Konwencjonalne oczekiwania metodologiczne przyjmują zewnętrznie postać imperatywu. Nie oznacza to, że należałoby z nich rezygnować, lecz jedynie wskazuje, że ich literalne stosowanie może preparować samo znaczenie. Mechaniczne stawianie problemu badawczego nie uwzględnia często jego roli w układzie powiązania go z tezą oraz hipotezami (dosłownie bądź pośrednio wskazanymi w tekście). Wskazanie na istnienie problemu w konsekwencji kieruje nas na konieczność postawienia pytania wobec analizowanych zjawisk, nie jest zaś uznaną projekcją samego zjawiska ${ }^{33}$. W efekcie spotykamy się z dość kategoryczną deklaracją wyjaśnienia zjawiska politycznego, przy czym finalnie nie jest to wyjaśnienie, lecz próba zrozumienia, a dodatkowo

32 Czy tytuł artykułu odpowiada treści?; Czy cel artykułu jest wyraźnie określony i zrealizowany?; Czy problem badawczy został sformułowany poprawnie? Czy artykuł posiada logiczna strukturę?; Czy wnioski wynikaja z treści pracy?; Czy autor opisuje metodykę badania oraz przebieg procesu badawczego? Czy artykut jest poprawny pod względem metodologicznym?

33 S. Nowak, Metodologia badań społecznych, Warszawa 2010, s. 30. 
brakuje pytań o sam problem. Klasycznym przykładem będzie umieszczenie w tytule sformułowania: „problem x”, który następnie ujmuje się przestrzennie i/lub temporalnie. Zarzut wiąże się ze starannością używania terminów naukowych, silnie uwarunkowanych ich potocznym znaczeniem. Ocena kreacji tytułu: "problem $x$ w miejscu $y$ w czasie $z$ ” jako problemu badawczego opiera się na jego metodologicznym przekształceniu w treści, nie zaś na dosłownej nagłówkowej deklaracji. Pojawia się kolejny dylemat, z jakim mierzy się recenzent, czy tekst treściowo odnoszący się do zjawiska, lecz nie mający metodologicznej kwalifikacji problemowej można ocenić jako spełniający wymóg postawiony w pytaniu. Tekst aspirujący do zasobów nauki, jednak mający status przedteoretyczny, przy tym reprezentujący spójność tematyczno-treściową w sposób przedmetodologiczny, winien być odrzucony z powodu istotnego rozmijania się z konwencją metanaukową.

Każda deklaracja metodologiczna zawiera w sobie nakaz jej spełnienia. Jeśli decydujemy się na wskazanie hipotez, to z założeń filozofii nauki płyną zobowiązania do ich empirycznej weryfikacji bądź konfirmowalności lub falsyfikacjii ${ }^{34}$. Wiąże się to ściśle z żądaniem zawartym w recenzji, aby ocenić stopień „wyrazistości i wypełnienia” celu artykułu. Szczególnie w tym konkretnym momencie uwidacznia się problem uniwersalności politologii jako dyscypliny nauk społecznych. Stanowisko dedukcjonistów oraz indukcjonistów wobec empirycznej rozstrzygalności politologicznych hipotez w konsekwencji prowadzi do podobnego skutku, a oznacza on brak obiektywnych możliwości obalenia bądź potwierdzenia tezy ${ }^{35}$. Autorska deklaracja o spełnieniu jednej z naukowych klauzul wobec przyjętej hipotezy musi być w politologii oceniana nie jako naukowa ekspresja, lecz jako błąd poznawczy. Naiwność empiryczną ${ }^{36}$ politologów, odnoszącą się do możliwości wdrożenia profesjonalnych obserwacji i ich skutków, obrazują poniższe słowa Kazimierza Jodkowskiego: „to, jakie informacje uczeni odbiorą, zależy od ich wizji świata, która jest ukonstytuowana przez szeroko rozumiane teorie, to jest przez założenia, przypuszczenia, hipotezy. Zdania obserwacyjne w związku z tym nie zdają sprawy z rzeczywistego wyglądu świata zewnętrznego wobec podmiotu poznającego. Obserwacje wizualne nie są sposobem uzyskiwa-

${ }^{34}$ Por. K. Jodkowski, Nienaukowy fundament nauki, [w:] Granice nauki, red. Z. Pietrzak, „Lectiones \& Acroases Philosophicae" 2013, t. VI, nr 1, s. 76-87.

35 Por. B.K. Mozer, op.cit., s. 51-52.

${ }^{36}$ Por. D. Sanders, Behawioryzm, [w:] Teorie i metody w naukach politycznych, red. D. Marsh, G. Stoker, Kraków 2006, s. 49-52. 
nia bezpośredniego kontaktu $\mathrm{z}$ otaczającą nas rzeczywistością. [...] Zdają one sprawę z wyglądu czegoś, co jest wytworem mózgu, czyli hipotetycznego, a nie realnego, obrazu otaczającej nas rzeczywistości. Mózg tę hipotezę tworzy na podstawie otrzymywanych ze zmysłów bodźców, ale nie tylko z nich" ${ }^{37}$. W tym ujęciu spór pomiędzy zwolennikami podejścia dedukcyjno-hipotetycznego a idiograficzno-indukcyjnego dla samej metateorii politologii nie ma większego znaczenia. Możemy bowiem spotkać zwolenników twardych kognitywnych linii demarkacyjnych, ale również stanowiska postulujące podejście syntetyczne. Kompromis poznawczy politologów odnosi się bowiem przede wszystkim do tego, czego politologia nie rozstrzyga, a nie tego, co wyjaśnia. Uteoretyzowanie obserwacji jest w zasadzie dość powszechną praktyką w naukach politycznych. Obserwujemy zjawisko poprzez nadawane samemu oglądowi przyczyny jego powstania ${ }^{38}$. Jego zrozumienie podobnie jak zaobserwowanie sprowadzić można do ich uwikłania w teorie przez nas poznane oraz preferowane. Dzieje się tak w myśl twierdzenia o niemożliwości rozstrzygania problemu na bazie samej obserwacji.

Dodatkowo rejestrujemy włączanie do asortymentu badawczego politologów pojęć, zdających relację z powierzchownej obserwacji, przy czym nadaje się im formę płytkich, zapożyczonych z narracji publicystycznej, metafor w rodzaju lemingów, postpolityki czy tabloidyzacji. Zarzuty nie dotyczą jednak samego użycia metafor, co oczywiście jest jak najbardziej dopuszczalne i czynienie oskarżenia z ich stosowania byłoby reglamentowaniem dyskursu. Chodzi jedynie o ich wąskie ujęcia, które kompresują często nowo obserwowane zjawisko do postaci pojedynczej cechy. Problemem nie jest więc pozanaukowe miejsce powstania terminu, tylko jego nienaukowa kreacja. Obiektywny trud zaczyna stanowić recenzyjna konieczność odseparowania aktu nadającego i wikłającego znaczenie pojęcia od jego naukowej analizy. Wydanie takiego werdyktu zwykle bywa odrzucane przez aproksymatyczną redukcję pod hasłem: „,wszystko jest polityką". Budzi uzasadnioną wątpliwość to, czy ów wybór zagadnienia z istotnego nie przemienia się w popularne. Czy wobec tego autor artykułu nie stawia się w roli głównego czytelnika, zakładając, że dany temat na pewno się „sprzeda”, a gratyfikacją będą cytowania? „Metafory i opowieści (niestety) oddziałują na nas znaczenie silniej niż idee; a przy tym są łatwiejsze do zapamiętania i przyjemniej

${ }_{38}^{37}$ K. Jodkowski, op.cit., s. 89-90.

38 A. Grobler, op.cit., s. 70-71. 
się je czyta"39. Stąd roszczenie wobec spójności tytułu i treści musi uwzględniać specyficzną dla niejednorodnych uczestników dyskursu politycznego skłonność do absolutyzowania spostrzeżeń, która na poziomie naukowym zastępuje uteoretyzowanie obserwacji.

Holistyczna inżynieria metodologiczna, mająca zdyscyplinować całe środowisko politologów, jest par excellence przeciwskuteczna. Same odwołanie się do metod to skutek wzajemnego sprzężenia osobistej deklaracji oraz zewnętrznego postulatu współczesnych naukowych narracji. O ile wiemy, że pełny obiad składa się z dwóch dań i deseru, to trudno zakładać, że mechaniczne odwzorowanie schematu wnioskowania $\mathrm{w}$ dowolnym badaniu niezawodnie prowadzi nas do wypełnienia klauzuli naukowości i stwierdzenia prawdy poprzez egzemplifikację dedykowanych założeń. Tylko pogłębiona świadomość metodologiczna, wyrażająca się zrozumieniem samych procesów poznawczych, niekoniecznie pojmowanych w sposób absolutystyczny, pozwala skonstruować cel artykułu, którego osiągnięcie ma walory aplikacyjne. Ocena celowości artykułu uzależniona jest od właściwego rozpoznania metanaukowych orientacji podmiotu recenzowanego oraz recenzującego ${ }^{40}$.W praktyce nie muszą być one tożsame.

Krytyka logicznego układu artykułu polega na weryfikacji jego struktury, a ta $\mathrm{z}$ kolei wiąże się z zoptymalizowanym modelem prowadzenia narracji, składającym się najczęściej ze słów kluczowych, abstraktu, wstępu (introdukcji), części zasadniczej wykładu oraz podsumowania. Choć brak jest takiego explicite wyrażonego nakazu w Arkuszu, to jednak można to pośrednio wyprowadzić z pytania: czy autor opisuje metodykę badania oraz przebieg procesu badawczego? Pytanie to dotyczy również samego wyartykułowania założeń metodologicznych. Przyjęty w ten sposób typ jest wynikiem intersubiektywnego namysłu nad przejrzystością nie tylko treści, ale również formy tekstu. Ta ostatnia jest także funkcją aplikacji i popularyzacji oraz komunikowania badań. W tym wypadku ewentualne zarzuty nie tyle mają deprecjonować zwyczaje autora, ile zewnętrznie umożliwiać mu prawo do obiektywizującej oceny oraz zaspokojenia osobistych celów naukowych, co często ma prymarne znaczenie. Natomiast wymóg wynikania wniosków z treści sprowadzić można do dwóch założeń. Po pierwsze w konwencjonalnym ujęciu wniosków jako zestawu sądów o zjawisku daje się dość swobodnie wykazać istnienie takiego związku. Po drugie wniosek

${ }^{39}$ N.N. Taleb, Czarny Łabędź: o skutkach nieprzewidywalnych wydarzeń, Warszawa 2014, s. 30.

40 Por. J. Nocoń, Przedmiot badań politologicznych jako polifoniczna interpretacja polityki, [w:] Metafory polityki..., op.cit., s. 58-60. 
widziany jako efekt wyboru schematu poznawczego: wyjaśniania bądź rozumienia (opcjonalnie deklarowanej ich syntezy) musi na poziomie treści z tym założeniem korespondować, a nie rozmijać się w stopniu znacznym.

\section{PODSUMOWANIE}

Intencją tego artykułu nie było skomplikowanie tego, co jawi nam się jako stosunkowo proste. Podstawowym zamierzeniem było przyjrzenie się obiektywnej potrzebie recenzowania tekstu mającego naukowe aspiracje poprzez obowiązującą kwalifikację metateoretyczną. Wspomniany na początku rozmyty przedmiot badania politologii, mimo zwielokrotnionych możliwości badawczych, nie powinien przesłaniać nam konieczności regresu do założeń metanaukowych, które choć nie mają charakteru praw obiektywnych, to jednak warunkują ogólnie, lecz nie uniwersalnie ocenę współczesnego dorobku dyscypliny. Naukowy determinizm wskazuje na nasze ograniczenia poznawcze i właśnie to należy uznać za największe osiągniecie empirystów. Jeśli w świecie badań politologów nie istnieją doskonałe założenia teoretyczne, można przez analogię podobny status przypisywać metateorii. Jednak trzeba pamiętać, że nie ma między innymi następstwa ani racji logicznej ${ }^{41}$. Co więcej, duża część terminologii stosowanej przez politologów używana jest przenośnie na poziomie postulowanej teorii oraz raczej adekwatnie w refleksji metateoretycznej.

Uwzględniając całościową konstrukcję arkusza recenzji „Athenaeum”, należy wskazać także na dwa paragrafy opisowe: ogólna ocena tekstu z uzasadnieniem oraz sugerowane poprawki. Poprzez przyjęte parametry metateoretyczne część tę obok argumentacji ewaluacyjnej można potraktować jako opis stanowiska kognitywnego recenzenta. Zarazem ogólne zasady recenzowania dają sposobność do narzucenia własnych preferencji epistemologicznych. Jeśli to wszystko zostanie uwzględnione przez autora, to obok intersubiektywnego dążenia do prawdy $y^{42}$ istnieje prawdopodobieństwo, niezależnie od jego potencjalności, doktrynalnego traktowania samego naukowego poznania. W ten sposób dominujące znacze-

41 J. Woleński, Spór o status metodologiczny nauki o polityce, [w:] Metodologiczne i teoretyczne problemy nauk politycznych, red. K. Opałek, Warszawa 1975, s. 44.

42 Nauka a świat wartości. Rozmowa z Grzegorzem Białkowskim, [w:] W. Osiatyński, Zrozumieć świat. Rozmowy z uczonymi 25 lat później, Warszawa 2009, s. 72. 
nie może zyskać preferowany sposób wnioskowania, co do pewnego stopnia mogłoby redukować postęp naukowy w dyscyplinie.

Osobliwie polskim przypadkiem, wynikającym prawdopodobnie $\mathrm{z}$ interpretacji koncepcji „Polskiego Wskaźnika Wpływu”, opisywanej przez profesora Jerzego Wilkina ${ }^{43}$, jest jakaś nieuzasadniona niechęć do kwantyfikacji dorobku naukowego polskojęzycznych autorów. Wymagałaby ona pogłębionych studiów socjologicznych oraz psychologicznych, które ułatwiałyby zrozumienie wyrażanych w recenzjach ocen podważających naukową wartość myślenia pozaanglojęzycznego.

43 J. Wilkin, op.cit. 